\title{
IMPACT OF RELATIONS BETWEEN EMPLOYEES AND CUSTOMERS TO THE CUSTOMERS' POSITIVE WORD-OF- MOUTH IN REAL ESTATE INDUSTRY
}

\author{
Phan Nhat Nam ${ }^{1}$, Nguyen Minh $\mathrm{Ha}^{2}$, Nguyen Huu Dung ${ }^{3}$ \\ ${ }^{1,2}$ Ho Chi Minh City Open University \\ ${ }^{3}$ University of Economics Ho Chi Minh City
}

(Received: 08/11/2015; Revised: 02/12/2015; Accepted: 07/12/2015)

\begin{abstract}
The study aims to explore and measure the relationship between employees and customers impacting positively to the word-of-mouth of customers who bought house from the real estate developers in Ho Chi Minh City. The study was based on survey data from 300 customers who bought house from the real estate developers in Ho Chi Minh City and using techniques of Cronbach Alpha analysis and Exploratory Factor Analysis (EFA). The study shows 4 factors of customer relationship affecting positively customers' word-of-mouth, including: (1) Familiarity; (2) Personal connection; (3) Care; (4) Trust. From the findings, the study suggests some policy implications to the real estate developers to improve the customers ' positive word-of-mouth.
\end{abstract}

Keywords: Caring, Familiarity, Relationship between Employee and Customer, Personal connection, Trust, Word-of-Mouth.

\section{Introduction}

For the real estate developers, customer is the most important factor affecting the survival and development of enterprises. Building a good relationship with customers is an important factor in building up enterprise' revenue and brand-name. Customers often carefully do research before buying; beside the information from consultants, websites, media, getting the review from friends, relatives has a huge influence on purchasing decision. According to the statistic of National Association of Realtors (NAR) about the effective marketing channels in real-estate transactions, the most successful and effective channel is through the introduction and word-of-mouth which account for over $48 \%$. Based on the study of
W\&S Ltd Company (Japan) in surveying 200 buyers in Ho Chi Minh City and Hanoi conducted in 2012, there are $80 \%$ of respondents get information from family, relatives and $72 \%$ from asking friends and colleagues to buy their own home.

Currently, many real estate enterprises in Ho Chi Minh City do not fully realize the importance of former customers' word-ofmouth but mainly focus on advertising media to increase sales, potential customers and company image. The study gives an overview to the leaders of the real estate enterprises on the issue of the relationship between employees and customers positively affect word-of-mouth. Moreover, it also proposes the policy implications to improve the relationship between employees and 
customers which create positive word-ofmouth, with the purpose of getting more customers and revenue for those enterprises, as well as building brand's reputation on the market.

\section{Literature review and hypothesis}

Word-of-mouth (WOM): Johan Arndt et al. (1967) defined the word-of-mouth: "Direct verbal communication between a recipient and a communicator relating to a brand, a product or a certain service and the recipient aware that the message from sender is noncommercial". Therefore, the element from person to person is not the only verbal communication method when electronic technologies, social network...in today's modern world are also considered as a mean for verbal communication (Buttle, 1998). According to Kirby and Marsden (2006), word-of-mouth is the speech, communication between persons, between the recipient and sender related to a brand, a product, service or information on the market, or a conversation between two or more person related to the products and service, independently to any enterprise.

The relationship between employees and customers creates positive word-of-mouth

There are four structural hypothesis components of the relationship between employees and customers which affect wordof-mouth, shown in Figure 1.

Caring in the relationship between employees and customers: According to Gremler et al. (2000), Caring is customer's awareness to the employees who have customer service. The level of caring shown in the case between customers and employees can be explained by the principle of ownership relations. The interpersonal interaction between individuals tend to help those who helped them. The level of caring leading to trust is the motivation for the employee to execute customer service. The caring is as customer's awareness about the employees who really care about customers. The level of caring leading to trust is likely to be based on the employee's motivation shown by the acts of caring. The Trust is an important factor in the development of the relationship between customers and enterprises in the future (Gremler et al., 2001). So, hypothesis 1 is given as follows

H1: Caring has a positive influence on customer's trust in the employees.

The familiarity in the relationship between employees and customers: Familiarity is defined as the customer's perception of the employee having personal feeling towards the customer and understands about their needs. (Gutek, 1999). The familiarity of customer with a service or an employee is as a synonym of the concept "Customers' knowledge first". This means that due to being influenced by familiarity from the previous collaboration with employees and enterprise lead to customers making decisions (Alba and Hutchinson, 1987). Also according to Alba and Hutchinson (1987), familiarity leads to better personal confidence and in some situations reduce the hesitation possibly causes customers' embarrassment, familiarity can operate as a subjective mechanism reducing uncertainty and simplifying the relationships. In the context of service provision, customer understanding is developed through repeated meetings, as a result, the employees become familiar with the customers and their demand for specific services. The familiarity also appears to play a role in the development of customer's trust, in relationship between employee and customer, having a positive relationship with the customer's familiarity (Gremler et al., 2001). Therefore, the second hypothesis is given following

H2: Familiarity has a positive influence on customer's trust in the employee.

Personal connection in the relationship between employees and customers: Personal 
connection is like a strong sense of the connection between individuals together. Personal connection is often based on some common attributes (such as personality and attitude) or benefits (e.g. growing up in the same neighborhood). Individuals perceived problem in a similar degree are more likely to form relationships. The more awareness between customer and employee increase, the more customers' trust will be. The concept of personal connection in a service relationship is relied on customer's perception about a relationship between two parties (Gremler et al., 2001). Knowledge is really developed when the enterprise' employees and customers have an emotional connection and connected as the relationship between individuals. The relationship between employee and customer is developed in the context of friendly encounters. Personal connection can shorten repeated transactions. When there is a personal connection between employee and customer, there will be an increase customer' trust in employee. A profound expression of the employee will bring customers' relative assessments of service quality to a higher level. Personal connection relates to the customers' perception of the interactions that take place during the process of providing service including the attitude, behavior and expertise of employee. (Gremler et al., 2001). Hence, hypothesis 3 is suggested

H3: Personal connection has a positive influence on customer's trust in employees.

The trust in the relationship between employee and customer: The setup of trust between customer and employee, enterprise is the main factor in creating a relationship of mutual benefit and creating satisfaction and loyalty from the customer. In any period of business history, trust has become a basic concept for the transaction and exchange. Trust is the tendency of relying on another party that you trust (Gremler et al., 2001). Trust may be defined as between individuals, between enterprises, or between individuals and enterprise. This study focuses on the development of trust in a relationship between individuals, between customer and employee. In fact, the level of trust between individuals (employees and customers) is a strong predictor of buyers' commitment and trust to the enterprise, the relationship between customers and their future tendencies (Garbarino and Johnson, 1999). An important key of the relationship between employee and customer is mutual trust, or confidence in the reliability and comprehensiveness of an employee. As well as customers' trust increases in a certain employee, positive word-of-mouth information is also likely to increase (Gremler and Gwinner, 2000). Experimental study examining the interaction of employees and customers has realized that building the trust related much to supportive behavior on using the enterprises' services. In fact, when interpersonal reliability between individuals is a strong predictor of customers' commitment to an enterprise, the relationship between customers and their future intentions. The trust of the customer in the employee has a direct positive effect on the tendency to engage in positive word-of-mouth behavior (Morgan and Hunt 1994). So, hypothesis 4 is given.

H4: Trust of customers has a positive influence on word-of-mouth communication. 


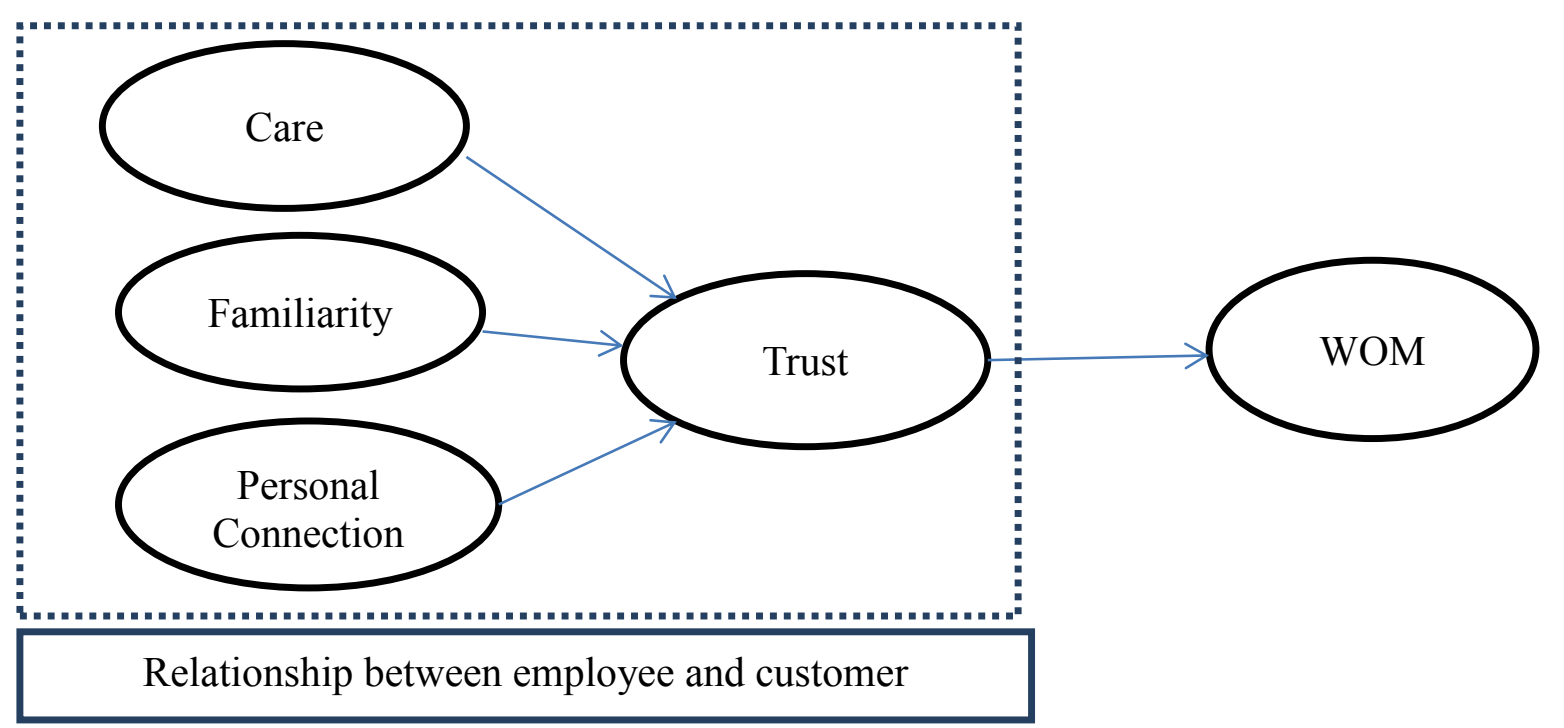

Figure 1. Suggested research model

\section{Research methodology}

Research is carried out in two steps: Qualitative and quantitative research.

Qualitative research is done through expert methods to explore, modify and supply the observed variables for scaling. During the design phase of scaling, there is discussion with 10 home buyers and the leaders of the real estate enterprises in Vietnam; scale calibrating phase discussion with 20 customers of the real estate enterprises in Ho Chi Minh City. The result adds some new scales; in which, the caring element adds two new scales, the familiarity element adds three new scales, personal connection element adds one new scale, the trust element adds two new scales and finally the word-of-mouth element also adds two new scales.

Study data is from directly interviewing customers through questionnaires at real estate developer offices. A sample is 300 customers and the study used five-level Likert scale. 300 valid questionnaires of customers who bought houses from the real estate developers in Ho Chi Minh City were analyzed. The quantitative study used SPSS software to analyze Cronbach's Alpha, EFA and multivariate regression model in order to determine the relationship between employee and customer affecting customers' word-ofmouth.

\section{Research results}

\subsection{Descriptive statistics}

According to the survey results, a total of 162 female customers accounted for $54 \%$ and 138 male customers accounted for $46 \%$. In terms of age group, the two biggest groups are the age of 31- 40 accounted for $37.3 \%$ and age-groups of 41-50 accounted for $37 \%$, these are two age-groups with the highest housing affordability; age-groups of 20-30 and over 50 years old accounted for $11.3 \%$ and $14.3 \%$ respectively. On the qualification level, customer group with a college degree or higher accounted for $94.4 \%$, therein, consumer group with qualified college/university account for $60.7 \%$, consumer group with postgraduate degree accounted for $33.7 \%$, customer group with a high school degree was made up of only $3.3 \%$ and customer group with a vocational degree account for only $2.3 \%$. Most of customers were living and working in Ho Chi Minh City with $89.3 \%$ and the rest was from other provinces. New customers with liaising time enterprise under a year comprised majority up to $45.3 \%$, followed by customers who have 1-2 years liaising time with $28.3 \%$, the former customers 
with 3-4 years and 5 years liaising time respectively accounted for $14.3 \%$ and $12 \%$. Most of customers buy one housing product had a high proportion of $60.7 \%$, followed by the group of buying 2-3 housing products with $33 \%$, the investing group with 4-5 housing products and more than 5 products respectively accounted for $3.3 \%$ and $3 \%$.

Table 1. Descriptive Statistics on survey sample by specification

\begin{tabular}{|c|c|c|c|}
\hline Factor & Element & Frequency & Percent \\
\hline \multirow{2}{*}{ Sex } & Male & 138 & 46.0 \\
\hline & Female & 162 & 54.0 \\
\hline \multirow{4}{*}{ Age } & $20-30$ & 34 & 11.3 \\
\hline & $31-40$ & 112 & 37.3 \\
\hline & $41-50$ & 111 & 37.0 \\
\hline & Over 50 & 43 & 14.3 \\
\hline \multirow{4}{*}{ Education } & High school & 10 & 3.3 \\
\hline & Vocational & 7 & 2.3 \\
\hline & College/University & 182 & 60.7 \\
\hline & Post-graduated & 101 & 33.7 \\
\hline \multirow{2}{*}{ Marital Status } & Single & 42 & 14.0 \\
\hline & Married & 258 & 86.0 \\
\hline \multirow{6}{*}{ Job } & Private & 96 & 32.0 \\
\hline & Private enterprise & 102 & 34.0 \\
\hline & State enterprise & 30 & 10.0 \\
\hline & Joint-venture & 11 & 3.7 \\
\hline & Foreign enterprise & 34 & 11.3 \\
\hline & Others & 27 & 9.0 \\
\hline \multirow{2}{*}{ Living place } & Ho Chi Minh City & 268 & 89.3 \\
\hline & Others & 32 & 10.7 \\
\hline \multirow{4}{*}{$\begin{array}{l}\text { Working time to the } \\
\text { enterprise }\end{array}$} & Under 1 year & 136 & 45.3 \\
\hline & $1-2$ years & 85 & 28.3 \\
\hline & $3-4$ years & 36 & 12.0 \\
\hline & Over 5 years & 43 & 14.3 \\
\hline \multirow{4}{*}{$\begin{array}{c}\text { Number of buying } \\
\text { product }\end{array}$} & 1 & 182 & 60.7 \\
\hline & $2-3$ & 99 & 33.0 \\
\hline & $4-5$ & 10 & 3.3 \\
\hline & Over 5 & 9 & 3.0 \\
\hline
\end{tabular}

\subsection{Cronbach's Alpha}

Studying scale is evaluated through Cronbach's Alpha testing from over 0.6 and the result of analysis on discovery factor EFA has loading index $\geq 0.5$. The results are shown in Table 2. 
Table 2. Cronbach's Alpha result for the elements

\begin{tabular}{|c|c|c|c|c|}
\hline Item & $\begin{array}{c}\text { Scale Mean if Item } \\
\text { Deleted }\end{array}$ & $\begin{array}{l}\text { Scale Variance if } \\
\text { Item Deleted }\end{array}$ & $\begin{array}{c}\text { Corrected Item-Total } \\
\text { Correlation }\end{array}$ & $\begin{array}{c}\text { Cronbach's Alpha if } \\
\text { Item Deleted }\end{array}$ \\
\hline \multicolumn{5}{|c|}{$\begin{array}{l}\text { Care }(C) \\
\text { Cronbach's Alpha }=\mathbf{0 . 7 4 8}\end{array}$} \\
\hline $\mathrm{C} 1$ & 17.32 & 2.855 & .570 & .682 \\
\hline $\mathrm{C} 2$ & 17.30 & 2.965 & .526 & .699 \\
\hline C3 & 17.25 & 2.972 & .513 & .703 \\
\hline $\mathrm{C} 4$ & 17.31 & 3.011 & .473 & .718 \\
\hline C5 & 17.28 & 3.020 & .480 & .715 \\
\hline
\end{tabular}

\section{Familiarity (F)}

Cronbach's Alpha $=\mathbf{0 . 8 2 7}$

\begin{tabular}{|c|c|c|c|c|}
\hline F1 & 25.04 & 9.035 & .576 & .804 \\
\hline F2 & 25.20 & 8.607 & .592 & .801 \\
\hline F3 & 25.01 & 9.284 & .528 & .811 \\
\hline F4 & 25.01 & 8.588 & .642 & .792 \\
\hline F5 & 25.10 & 8.817 & .637 & .794 \\
\hline F6 & 25.08 & 9.428 & .517 & .813 \\
\hline F7 & 25.28 & 8.799 & .524 & .814 \\
\hline
\end{tabular}

Personal Conection (PC)

Cronbach's Alpha $=\mathbf{0 . 7 8 1}$

\begin{tabular}{|l|l|l|l|l|}
\hline PC1 & 20.89 & 5.275 & .638 & .724 \\
\hline PC2 & 20.85 & 5.176 & .629 & .724 \\
\hline PC3 & 21.10 & 5.118 & .538 & .746 \\
\hline PC4 & 21.13 & 5.308 & .421 & .780 \\
\hline PC5 & 20.92 & 5.669 & .495 & .757 \\
\hline PC6 & 21.00 & 5.391 & .497 & .756 \\
\hline
\end{tabular}

Trust (T)

Cronbach's Alpha $=\mathbf{0 . 7 2 3}$

\begin{tabular}{|l|l|l|l|l|}
\hline $\mathrm{T} 1$ & 16.80 & 3.373 & .505 & .666 \\
\hline $\mathrm{T} 2$ & 16.95 & 3.278 & .517 & .661 \\
\hline $\mathrm{T} 3$ & 16.91 & 3.336 & .491 & .672 \\
\hline $\mathrm{T} 4$ & 16.78 & 3.612 & .419 & .699 \\
\hline $\mathrm{T} 5$ & 16.86 & 3.342 & .475 & .679 \\
\hline
\end{tabular}

Word of mouth (WOM)

Cronbach's Alpha $=\mathbf{0 . 7 8 5}$

\begin{tabular}{|c|c|c|c|c|}
\hline WOM1 & 20.65 & 6.122 & .448 & .771 \\
\hline WOM2 & 20.77 & 5.701 & .548 & .749 \\
\hline WOM3 & 20.78 & 5.443 & .610 & .734 \\
\hline WOM4 & 20.87 & 5.284 & .560 & .746 \\
\hline WOM5 & 20.83 & 5.555 & .519 & .756 \\
\hline WOM6 & 20.84 & 5.575 & .524 & .755 \\
\hline
\end{tabular}




\subsection{Results of EFA}

Analysis method on EFA (shown in table 3) has 18 observing variables put into the analysis. There are three variables excluded due to being unqualified: variable PC4 (I have a close relationship with employee) was excluded because of having elements index $=$ $0417<0.5$; F3 variable (I'd like to work/ask information with familiar employee) and $\mathrm{C} 3$ (Employee consults me very carefully and accurately) was excluded because of unable to guarantee the distinguishing value.

Table 3. Results of EFA

\begin{tabular}{|l|c|c|c|}
\hline \multicolumn{1}{|c|}{ Observed variables } & Symbol & $\begin{array}{c}\text { Factor } \\
\text { Loading }\end{array}$ & $\begin{array}{c}\text { Cronbach's } \\
\text { Anpha }\end{array}$ \\
\hline Familiarity & F & & $\mathbf{0 . 8 2 7}$ \\
\hline The employee makes me feel closely. & F1 & .618 & \\
\hline I am quite familiar with the products of this enterprise. & F2 & .745 & \\
\hline $\begin{array}{l}\text { I often buy the products of enterprise through my close } \\
\text { employee. }\end{array}$ & F4 & .694 & \\
\hline I am familiar with employees' working way & F5 & .681 & \\
\hline The employee is familiar with my working way & F6 & .627 & \\
\hline I am familiar with the procedure of enterprise & F7 & .660 & \\
\hline Personal Connection & PC & & $\mathbf{0 . 7 8 1}$ \\
\hline I can feel the friendship between the employee and me & PC1 & .769 & \\
\hline $\begin{array}{l}\text { I want to work/communicate with this employee when I } \\
\text { come to the enterprise }\end{array}$ & PC2 & .786 & \\
\hline I have many things in common with this employee & PC3 & .625 & \\
\hline $\begin{array}{l}\text { The employee takes me to the benefits when buying the } \\
\text { product }\end{array}$ & PC5 & .582 & \\
\hline I often discuss the issue outside of work with the employee & PC6 & .637 & \\
\hline Care & C & & $\mathbf{0 . 7 4 8}$ \\
\hline The employee makes me feel cared. & C1 & .735 & \\
\hline $\begin{array}{l}\text { I feel comfortable when interacting with enterprises' } \\
\text { employees. }\end{array}$ & C2 & .729 & \\
\hline $\begin{array}{l}\text { When there are updated news relating to products and } \\
\text { enterprise, the employee supplies for me in time. }\end{array}$ & C4 & .566 & \\
\hline $\begin{array}{l}\text { The employee takes care of me before, during and after } \\
\text { buying the enterprises' products. }\end{array}$ & C5 & .666 & \\
\hline
\end{tabular}




\subsection{Regression analysis result}

The equation of relationship between employee and customer

As can be seen from table 4 , the result shows that $\mathrm{R}^{2}=0.51$, meaning that about $51 \%$ of variance on customer trust is explained by three independent variables which are care $(\mathrm{C})$, familiarity $(\mathrm{F})$ and personal connections (PC). In ANOVA analysis table, sig. value is very small $(\operatorname{sig}=0.00)$, so the regression model fits the data set and can be used.

Table 4. Overall fit of the estimated model about the relationship between employee and customer

\begin{tabular}{|c|c|c|c|c|c|}
\hline Model & $\mathrm{R}$ & $\mathrm{R}$ Square & Adjusted R Square & $\begin{array}{c}\text { Std. Error of the } \\
\text { Estimate }\end{array}$ & Durbin-Watson \\
\hline & $.717^{\mathrm{a}}$ & .515 & .510 & .31156 & 1.929 \\
\hline
\end{tabular}

The regression results show that Therefore, at 95\% trust, independent variables independent variables: Care (C), Familiar (F) and Personal Connection (PC) have sig below 0.05 , so variables are at the trust level of $95 \%$. affect the dependent variable (T) and the index system has positive signal and variables affect positively the customer's trust.

Table 5. Results of regression model about the relationship between employee and customer

\begin{tabular}{|c|c|c|c|c|c|c|c|}
\hline \multirow{2}{*}{ Model } & \multicolumn{2}{|c|}{$\begin{array}{c}\text { Unstandardized } \\
\text { Coefficients }\end{array}$} & \multirow{2}{*}{$\begin{array}{c}\begin{array}{c}\text { Standardized } \\
\text { Coefficients }\end{array} \\
\text { Beta }\end{array}$} & \multirow{2}{*}{$\mathrm{t}$} & \multirow{2}{*}{ Sig. } & \multicolumn{2}{|c|}{$\begin{array}{l}\text { Collinearity } \\
\text { Statistics }\end{array}$} \\
\hline & B & Std. Error & & & & Tolerance & VIF \\
\hline Constant & .805 & .203 & & 3.958 & .000 & & \\
\hline Care & .210 & .051 & $.204 * *$ & 4.088 & .000 & .659 & 1.517 \\
\hline Familiarity & .362 & .044 & $.413 * * *$ & 8.185 & .000 & .644 & 1.553 \\
\hline Personal Connection & .235 & .049 & $.244 * * *$ & 4.795 & .000 & .635 & 1.574 \\
\hline
\end{tabular}

Dependent Variable: T

Note:**: Regression coefficients is significant at the 0.01 level (2-tailed).

The importance of the independent variables on the dependent variable is demonstrated by the standardized Beta. If the bigger the absolute value of the beta factor is, the more it influence on the loyalty of customers for the company. Therefore, the most important impact on customers' trust is friendly factor (Beta $=0.413)$, followed by the factor of personal connection $($ Beta $=0.244$ ) and finally, the care factor $($ Beta $=0.204)$.
The equation relationship between the trust of employee and customer with the positive customers' word-of-mouth

The result of regression model about the relationship between employee and customer to the customers' word-of-mouth came out relatively appropriate with the level of significance 0.05. $\mathrm{R}^{2}=0.508$ means that about $50.8 \%$ variance of customers' trust is explained by the independent variable Trust. 
Table 6. Overall fit of the estimated model about the trust of employee and customer towards the positive customers' word-of-mouth

\begin{tabular}{|l|l|r|r|r|r|}
\hline Model & $\mathrm{R}$ & \multicolumn{1}{|c|}{ R Square } & $\begin{array}{c}\text { Adjusted R } \\
\text { Square }\end{array}$ & $\begin{array}{c}\text { Std. Error of the } \\
\text { Estimate }\end{array}$ & Durbin-Watson \\
\hline 1 & $.714^{\mathrm{a}}$ & .510 & .508 & .32544 & 2.064 \\
\hline
\end{tabular}

Independent Variable: $\mathrm{T}$

Dependent Variable: WOM

In Table 7, the regression results show that the independent variable Trust (Relationship between employee and customer) has sig below 0.05 , so it has meaning at $95 \%$ trust. Therefore, at $95 \%$ trust, independent variable Trust (T) affects the dependent variable (WOM) and the index system with positive signal so it affects positively customer's trust.

Table 7. Results of regression model of the trust between employees and customers to the positive customers' word-of-mouth

\begin{tabular}{|l|r|r|r|r|r|}
\hline \multirow{2}{*}{ Model } & \multicolumn{2}{|c|}{ Unstandardized Coefficients } & $\begin{array}{c}\text { Standardized } \\
\text { Coefficients }\end{array}$ & \multicolumn{1}{c|}{$\mathrm{t}$} & \multirow{2}{*}{ Sig. } \\
\cline { 2 - 4 } & $\mathrm{B}$ & Std. Error & Beta & \\
\hline Constant & -.215 & .249 & & -.861 & .390 \\
Trust & 1.038 & .059 & $.714 * * *$ & 17.599 & .000 \\
\hline
\end{tabular}

Dependent Variable: WOM.

Note:***: Regression coefficients is significant at the 0.01 level (2-tailed).

\section{Discussions of regression results}

The regression results demonstrate the role of these factors in contributing to the increase of trust of customers, assigned distinctively by hierarchy, in which the familiarity plays the most important role. The familiarity has positive influence on the trust of customers. The study of Gremler et al. (2001) shows that in the field of banking, the familiarity has a positive impact on the trust of customers, but for the field of dentistry is the opposite: The familiarity has opposite relationship with the trust of customers. For the real estate sector, customers have a longterm liaising process with the enterprise tend to work with the employees who they feel friendly and understand how they do their jobs. Especially for cases when customers buy products repeatedly or new customers are introduced by old customers, they do not want to spend more time to work with new employees who have not known them clearly.

The regression result shows that personal connection factor has the second degree of influence on customer trust in relationship between employee and customer. Personal connection has positive influence on the trust of customers. The research of Gremler et al. (2001) in both fields of banking and dentistry totally shows personal connection has a positive relationship to the customer trust. Customers tend to trust the employee when 
they see the similarities. There are many kinds of similarities, such as living place, home town, hobby, member of a club, the same idol ... or deeper such as similarities in personality: Introvert or extrovert...When personal connection increases, customers often recommend employee for their relationships such as friends, relatives, business partners for the purpose of work and all close relationships. Meanwhile, employee will pay more attention to the interests of customers: asking for the sale promotion for customers, advising ways of working to reach the most economical way for customers. Thus, the trust of customers will increase and the level of personal connection between employees and customers continue to be developed.

The last element according to the regression results impact on customer confidence is care. Care has a positive influence on the trust of customers. The study of Gremler et al. (2001) in both fields of banking and dentistry shows that care has a positive relationship on the trust of customers. The care of employee to customers in the process before, during and after the customer purchases the product. When the real estate market becomes more transparent, the competition between enterprises increases, the customer care factor is considered one of the most preferred categories in enhancing enterprises' reputation and brand.

The study results show that the trust has a positive influence on customers' positive word-of-mouth. The study of Gremler et al. (2001) in both fields of banking and dentistry has the same result. Housing is an asset of great value to customers. The creation of the trust from customer to employee and enterprise must be experienced through a long-term working process, and must be guaranteed for the expectations and desires of the customers. Along with the transparency of the housing market growing up, the trust of customer plays more and more important role for the success of the enterprise.

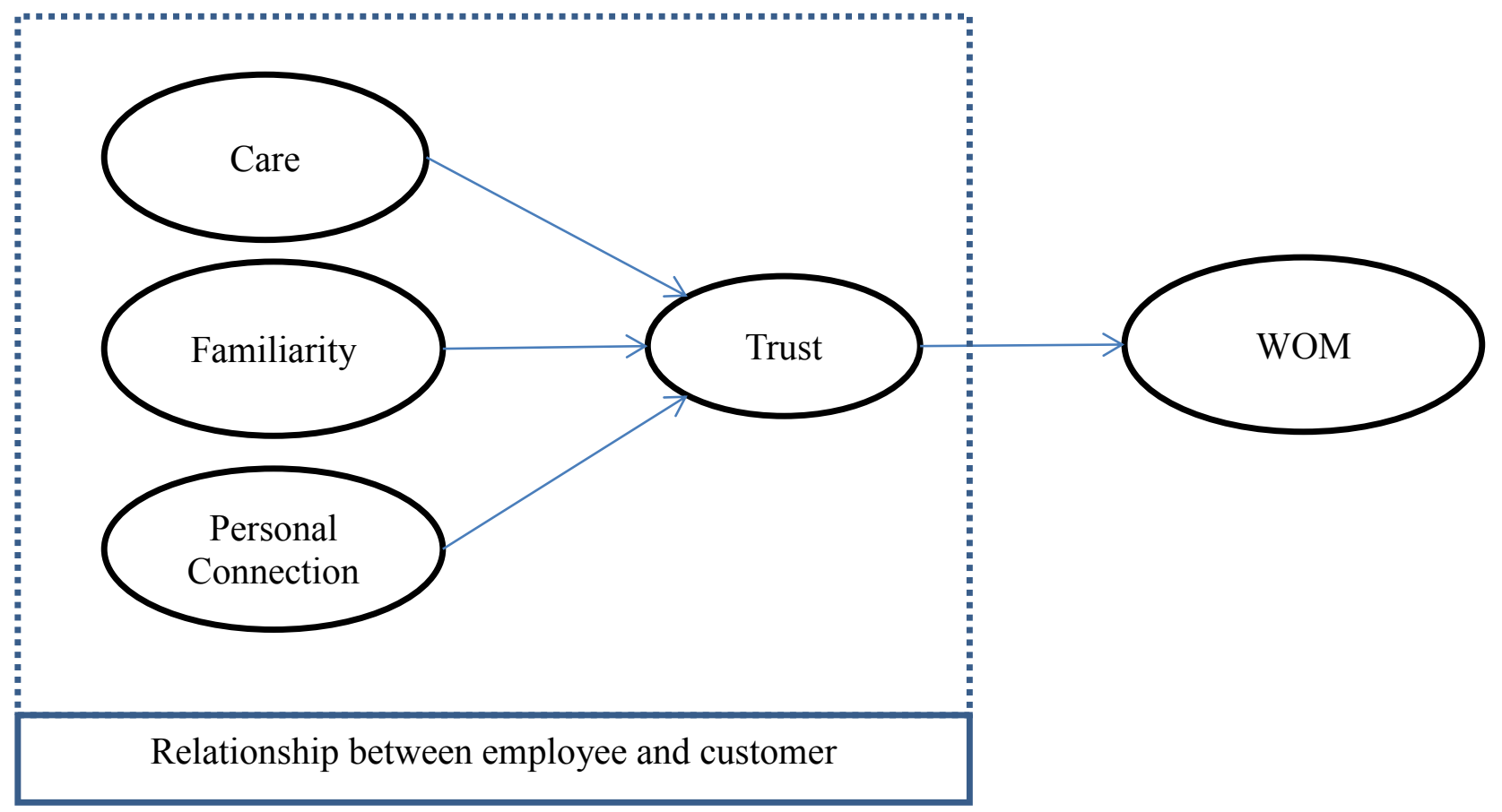

Figure 2. Results of regression model 


\section{Conclusion and managerial implications}

\subsection{Conclusion}

The study results show that the customers' word-of-mouth for real estate developers in Ho Chi Minh City is relatively high with an average of 4.16 in the five-level Likert scale.

In the relationship between employee and customer, in terms of each factor separately, the customer has the highest satisfaction with employee's familiarity, followed by personal connection and finally the employee's caring. When considering the relationship between employee and customer with observant variables, we can see the variable "Customers familiar with the procedure of enterprise" in element of familiarity is evaluated at an average of 4 , the variable "I have close relationship with employee" is evaluated at an average of 4.05. This shows that customer still get difficulties in the process of working with enterprise due to the processes and procedures when purchasing the house.

Linear regression analysis helped determine the intensity of three factors affecting customers' trust in the relationship between employee and customer. Therein, the familiarity has the greatest impact, followed by personal connection and finally care. The regression results show that the relationship between employee and customer to give positive word-of-mouth prove the model explaining $50.8 \%$ on the variation of customers' positive word-of-mouth factor.

\subsection{Managerial implications}

For familiarity: Enterprises still have difficult or inappropriate procedures to customers when buying a home. Enterprises need to have a standard procedure applicable to all their projects with ISO standards, this method should be expanded to apply for enterprises operating in the field of real estate.
For personal connection: Employees need make customers feel familiar with them during the working process, give the analytics to customer for their best choice. Enterprises need to train employees with basic knowledge in the relevant fields. Employees will create the trust of customers due to their sufficient knowledge which customers can rely on those consultancies to make their decision.

For care: Housing is a huge asset to customers so consulting information and advice must be truthful, accurate and detailed. Enterprises need to train employees to have more professional ethics besides the professional ability, avoid providing false information in order to serve the interests of employees and affect the interests of customers as well as enterprises' image. It's necessary that enterprises have policy and train employees to take good care of the customer even if the customer had already bought the product of enterprise.

Creating the trust of customers: The real estate developers should issue the principles to attach interests of sales to obligations and professional ethics. After-sales service, customer care need to be improved greatly. Trust brings superior and more sustainable benefits than conventional approaches, such as introducing or using other sales, communication techniques. Employee and enterprise should consult correctly about the product, avoid inflating to gain immediate profit.

One of the most popular reasons that make customers abandon enterprises is because they are not respected by the employees. It should be realized that the cost to keep an old customer and turn him/her into loyal customers is lower than searching for new customers, employees need to make effort to please and build the trust from customers. 


\section{REFERENCES}

Alba, Joseph W. and J. Wesley Hutchinson (1987). Dimensions of consumer expertise .Journal of Consumer Research, 13(March), 1987.

Arndt J. et al. (1967). Word-of-mouth advertising: a review of the literature, J. Arndt. - New York: The Advertising Research Foundation Inc, 1967.

Bansal, Harvir S. and Peter A. Voyer (2000). Word-of-Mouth Processes within a Services Purchase Decision Context. Journal of Service Research, November 2000 vol.3 no.2, 166177.

L. Bove and W. Johnson (2000)..A customer-service worker relationship model. International Journal of Service Industry Management, 11 (5), 491-511.

Buttle Francis A. (1998). Understanding and managing referral marketing. Journal of strategic marketing, 1998, Volume 6, Issue 3, 1998.

Garbarino E. and MS Johnson, (1999). The Different Roles of Satisfaction, Trust, and Commitment in Customer Relationships. Journal of Marketing, 63 (2), 70-87.

GremlerDwayne D. and GwinnerKevin P. (2000). Customer-employee rapport in service relationships. Journal of Service Research, August 2000 vol.3 no. 82-104.

Gremler, Dwayne D., GwinnerKevin P. and Stephen W. Brown (2001). Generating positiveword-of-mouth communicationthrough customer and employeerelationships. International Journal of ServiceIndustry Management, Vol.12 No.1, 2001.

Gutek (1999). The Social Psychology of Service Interactions. Journal of Social, IssuesVolume 55, Issue 3, pages 603-617, Fall 1999.

Kirby, J. and Marsden, P. (2006). Connected Marketing: The viral, buzz and word of mouth revolution, Oxford, UK.

Morgan M.\&Hunt D. (1994). The commitment-trust theory of relationship marketing. Journal of Marketing, 58 (July), 1994.

National Association of Realtors (2014). Profile of home Buyers and Sellers.

W\&S Vietnam (2014). Housing market in Hanoi and Ho Chi Minh City, January 2014. 